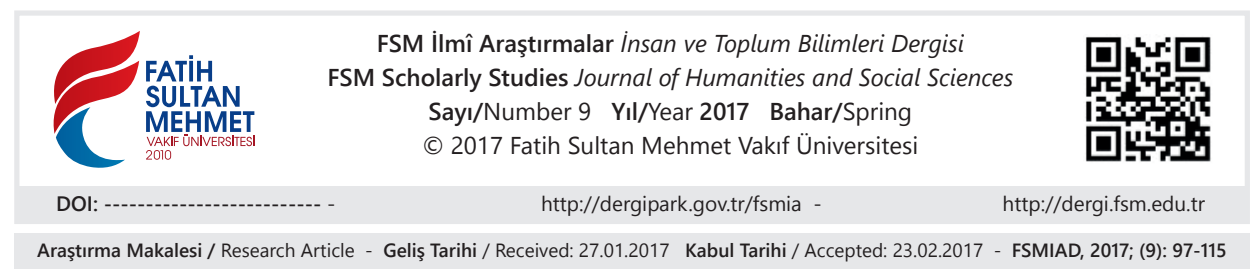

\title{
Nişâbur Ekolüne Mensup Hanım Sûfilerde Görülen Fütüvvet ve Melâmet Anlayışı
}

Hatice Çubukcu*

\section{Öz}

Hicrî III. ve IV. Yüzyıllarda tasavvuf hareketi içinde öne çıkan sûfî ekollerden biri de Nişâbur Ekolüdür. Nişâbur Ekolüne mensup sûfiler "melâmet ve fütüvvet" anlayışlarıyla dikkat çekmişlerdir. Bu ekole mensup hanım sûfîlerin tasavvuf düşüncelerinde de benzer eğilimi görmekteyiz. Çoğunlukla zamanın önde gelen sûfîlerinin yakınında yetişmiş olan bu hanımlarda fütüvvet; îsâr, tevekkül, eziyet vermemek, iyiliği yaymak, halka hizmet, fakirlere yardım şeklinde tezâhür etmiştir. Söz konusu hanım sûfiler tarafından melâmet de; riya endişesi, ihlâs, özel kıyafet ve törenlere karşı olma, nefsi ithâm ve aşağılama şeklinde yorumlanmıştır.

Anahtar Kelimeler: Riyâ, ihlâs, melâmet, fütüvvet, nefs.

\section{As Members of Nishapur School, Female Sûfî́ Understanding of Futuvva and Malama}

\section{Abstract}

One of the sûfî-schools that played a key role in the mystical movemnet in the $3 \mathrm{rd}$ and 4th centuries A.H. is, of course, Nishapur School. The sûfîs who were the members of Nishapur School drew attention with their understanding of 'Malama and Futuwwa'. It is apparent that female sûfîs who belonged to the same school cherished similar tendencies towards mystical thoughts. Futuwwa appeared in these female sûfîs who were trained by the sûfî-leaders who were distinguished at the time in such a way as altruism, absolute reliance on God, not causing any pain to living things or humans, making good deeds widespread, serving the public and helping the poor. Malama was viewed and characterized by these female sûfîs as blaming and disgracing one's own lower-self (nafs), refusing any kind of pirvate rituals and special clothes, sincerity and anxiety of hypocrisy.

Keywords: Hypocricy, sincerity, malama, futuwwa, nafs (lower self).

* Yrd. Doç. Dr., Ordu Üniversitesi İlahiyat Fakültesi, Ordu/ Türkiye, h_cubukcu@hotmail.com 


\section{Giriş}

Bu makalemizde "İlk Dönem Hanım Sufiler" isimli çalışmada ${ }^{1}$ yer alan Nişaburlu hanım sufilerin melâmet ve fütüvvet anlayışlarını daha da detaylandırarak ele almayı amaçlamaktayız.

İslam'ın manevî yönünü temsil eden tasavvuf akımı oluşum devresinden itibaren hanım müntesiplerinin çokluğuyla dikkat çekmiştir. Öyle ki, İbnü'l-Cevzî (ö.597/1201), Molla Câmî (ö.898/1492), Abdülvehhâb eş-Şa'rânî (ö.973/1565) gibi tabakât yazarları eserlerinde hanım sûfîlere geniş yer vermiş hatta Ebû Abdurrahman Sülemî (412/1021)'de olduğu üzere kadın sûfilerden bahseden müstakil eserler kaleme almışlardır. Şüphesiz Müslüman kadınların tasavvufî hayata olan teveccühlerinde tarihî, sosyolojik, psikolojik pek çok etkenden bahsedilebilir. Söz konusu etkenlerin en başında, tasavvufun kadın hususunda diğer İslamî disiplinlerden farklı, daha pozitif bir görüşünün olmasın1 $1^{2}$ sayabiliriz. Zâhirî ilimlerin aksine İslam tasavvufunda kadın erkek ayrımı en asgari sınırda tutulmuştur. Öyle ki, tasavvufî düşünceye göre mânevî alanda ulaşılabilecek en üst nokta olan "velâyet" mertebesine erişmede kadın erkek arasında fark yoktur. ${ }^{3}$ Kaynaklarda Râbia el-Adeviyye (ö.185/801) başta olmak üzere çok sayıda kadın evliyânın adı geçmektedir.

Ayrıca tasavvufun aklın ötesinde kalpte oluşan ilhâmî bilgiye önem vermesi kadınları ona yaklaştıran bir diğer unsur olmuştur. Zira ilahî sırlara ve hakikâtlere ulaşmanın yolu olan aşk, şevk, vecd, muhabbet gibi hususlar kadınlarda daha güçlü şekilde tezâhür etmektedir. ${ }^{4}$

Kısacası her devirde hanım sûfîlerin tasavvufî düşünceye fazlaca rağbet ettiklerini ve bu düşünceye önemli katkı sağladıklarını söyleyebiliriz. Dolayısıyla tasavvufî düşüncenin zaman içinde belli ekollere ayrılmasıyla da hanım sûfîlerin, mensubu oldukları ekollerin öne çıkan söylemleri doğrultusunda tasavvuf anlayışlarını oluşturdukları görülmüştür. Ekseriya dönemin önde gelen sûfîlerinin etrafında yetişmiş olan bu hanımlar, mevcut tasavvufî anlayışı yansıtmalarının yanında, tasavvufî düşünceye orijinal açılımlar getirebilecek kabiliyete de haiz idiler. Özellikle H. III. ve IV. asırlarda, anlatılan bu özelliklerde -tasavvufî düşüncede yaşanan canlılığa paralel olarak- azımsanamayacak sayıda hanım sûfî yetişmiştir. Bilindiği gibi bu asırlarda görülen belli başlı tasavvufî ekoller; Bağdat,

1 Bknz: Hatice Çubukcu, İlk Dönem Hanım Sufiler (H.I-V/M.VII-XI Yüzyıllar), İnsan Yayınları, 2006.

2 Annemarie Schimmel, İslamın Mistik Boyutları, çev.Ergun Kocabıyık, İstanbul, Kabalcı yayınevi, 2001, s.413; Süleyman Uludağ, Sûfi Gözüyle Kadın, İstanbul, İnsan Yayınları, 1995,s.13.

3 Margaret Smith, Bir Kadın Sûfi Rabia, çev.Özlem Eraydın, İstanbul, İnsan yayınları, 1991,s. 37.

4 Uludăg,age.,s.55. 
Mısır, Şam, Nişâbur şeklinde tespit edilmiştir. ${ }^{5}$ Çalışmamızda Nişâbur ekolünde öne çıkan fütüvvet ve melâmet anlayışlarının, özellikle bu ekole mensup hanım sûfîler nezdindeki algılanış şekli üzerinde durup, onların bu husustaki ifadelerini değerlendirmeye çalışacağız. Ancak öncelikle fütüvvet ve melâmet kavramlarından kısaca bahsetmenin faydalı olacağı kanaatindeyim.

Fütüvvet kavramının kendinden türediği ve genç, delikanlı, yiğit anlamlarına gelen fetâ ${ }^{6}$ kelimesi İslam öncesi Arap toplumunda kullanılmaktaydı. Öyle anlaşılıyor ki, fetâ kelimesi bazı merhaleler geçirmiş; din dışı nötr bir anlama sahipken zamanla dinî ve tasavvufî bir hüviyet kazanmıştır. Zamanla tasavvufî bir mâhiyete bürünen fetâ kelimesi önceleri toplumsal hayatta bir ideal iken sonraları fütüvvet adıyla rûhânî hayatta ideal haline gelmiştir. ${ }^{8}$ Fetâ isminin Kur'ân'da geçiyor olması şüphesiz onun kavramlaşma sürecini olumlu yönde hızlandırmıştır. Kur'ân'da fetâ (fitye, fetayât) diye nitelendirilen' kişiler için bu sıfat dînî bir mânâ taşımanın yanında takdir edilen bir anlam ifade etmektedir. Buna göre put kıran ${ }^{10}$ veya gördükleri baskıya rağmen inançlarını koruyan ve bu uğurda ülkelerini terkeden kişilerden fetâ diye söz edilmektedir. ${ }^{11}$ Bundan dolayı halk arasında takdir edilen bir vasıf olan yiğitliği Kur'an'daki fetâ ifadesiyle irtibatlandıran sûfîler onu yaygın bir tasavvufî kavram olarak kullanmaya başlamışlardır. Başlangıcından kurumsallaşmasına kadar oldukça uzun bir serüveni olan fütüvvet kavramının araştırmacılar tarafından tespit edilen tarihî merhaleleri şu şekildedir:

1) İslâm öncesi dönem (cahiliye dönemi)

2) İslâm'ın ilk asırları

3) Tasavvufî fütüvvet dönemi

4)Abbasî Halifesi Nâsır- Lidînillâh (ö.1180/1225) dönemi

5) Ahîlik fütüvveti veya ahîlik dönemi. ${ }^{12}$

Söz konusu bu dönemlerden konumuzla alakalı olan, mâlûm olduğu üzere tasavvufî fütüvvettir. Kaynaklarda fütüvvet ehlinden oldukları söylenen kişilere

5 Ebu'l-Alâ Afifî, Tasavvuf İslamda Manevî Hayat, çev. Ekrem Demirli-Abdullah Kartal, İstanbul, İz yayıncılık,1999, s.83; H.Kamil Yılmaz, Anahatlarıyla Tasavvuf ve Tarikatler, İstanbul, Ensar Neşriyat, 1997, ss.111-120.

6 Hüseyin b. Muhammed Râgıb Isfahânî, el-Müfredât fì Garîbi'l-Kur'an, Kahire, 1961, s.372.

7 Ali Bolat, Bir Tasavvuf Okulu Olarak Melâmetîlik, İstanbul, İnsan yayınları, 20003, s.257.

8 Mehmet Demirci, “Ahîlik’te Tasavvufî Boyut: Fütüvvet”, Dokuz Eylül Üniversitesi Illahiyat Fakültesi Dergisi, c.7, İzmir ,1992, s. 84.

9 Kur'an, en-Nisâ ,4/25; Yûsuf,12/ 30,36,62; el-Kehf, 18/60,62.

10 Kur'an, el-Enbiya 21/60.

11 Kur'an, el-Kehf 18/10,13.

12 Sezai Küçük, “Abdullah Ensârî el-Herevî’nin Tasavvufî Fütüvvet Risâlesi: "Kitâbu'l-Fütüvvet”, Sakarya Üniversitesi İlâhiyat Fakültesi Dergisi, c.2, Sakarya, 2000, s.138. 
bakıldığında bu anlayışın Horasan, Şam, Bağdat başta olmak üzere ${ }^{13}$ sûfî düşüncenin uzandığı her yerde benimsendiği görülmektedir. Horasan bölgesi içinde hicrî III. ve IV. yy da öne çıkan bir merkez olan Nişâbur mektebinde fütüvvet ehlinden Fudayl b. İyâz (ö.187/803), Ahmet b. Hadraveyh (ö.240/845), Ebû Hafs Haddâd (ö.270/884), Ebû Türâb Nahşebî (ö.245/859), Ebû Abdullah es-Siczî, Ebu'l-Hasan Büşencî (ö. 348/959), Ebû Osman Hîrî (ö.298/910), Ebu'-1 Kâsım Nasrâbâzî (ö.372/982), Hâtim el-Esam (ö.237/851) gibi isimleri sayabiliriz. Fütüvvet anlayışı anılan zevatın elinde asabiyet ve kabileciliğe dayalı bir îsâr anlayışından kurtarılarak mürüvvet ile birlikte isâr merkezli fakat genel anlamda ahlâkî erdemlerin toplandığı bir kavram haline getirilmeye çalışılmıştır. ${ }^{14}$ Tasavvufta fütüvvet terimiyle; fedakarlık, diğerkamlık, iyilik, yardım, insan severlik, hoşgörü, ve nefsine sözgeçirme gibi ahlakî nitelikler kastedilmiştir. ${ }^{15} \mathrm{Bu}$ konuda, Ebü'l-Hüseyin en-Nûrî (ö.295/907)'nin fütüvveti, tekellüfü terk ve cömertlik şeklinde tarif etmesiyle ${ }^{16}$ Ebû Hafs Haddâd'ın, insaf etmek fakat insaf istemeyi terketmek, ${ }^{17}$ Fudayl b. İyâz'ın, dostların kusurlarını hoş görmek ${ }^{18}$ şeklindeki fütüvvet tariflerini örnek olarak zikredebiliriz Fütüvvet kavramının ilkeleri yazılı olarak Ebû Abdurrahman Sülemî (ö.412/1021), Ebu'l-Kâsım Kuşeyrî (ö.465/1072), Abdullah el-Ensârî el-Herevî (ö.481/1088), Ebû Hafs es-Sühreverdî (ö.632/1234) gibi sûfî müelliflerce tespit edilmiştir. Sülemî'nin fütüvvet risâlesi bu husustaki en erken çalışmadır. Onun derlediği fütüvvet ilkeleri şu şekildedir: "Doğruluk, vefa, cömertlik, güzel huy, göz tokluğu, dostlarla şakalaşma, arkadaşlarla iyi geçinme, kötü söz söylemekten kaçınma, iyilik yapmayı arzulama, güzel komşuluk yapma, güzel konuşma, ahde vefa, aile efradına ve hizmetçilere iyi davranma, çocukları güzel terbiye etme, Allah için dost ve Allah için düşman olma, malını mülkünü dostlara harcama ve bu iyiliği başa kakmamak, misafirlere hizmet etme, canıyla malıyla dostların işine koşma, kötülüğe iyilikle karşılık verme, mütevâzi olma, kibirlenmeme, ana-babaya iyilik etme, akrabayı ziyâret etme, ihvânın kusurlarını örtme ve gizliden onlara ögüt verme, onlara dua etme, halk ile ülfet etme, fakirlere acıma, fakirlerle oturmaktan şeref duyma, zenginlere zenginliklerinden dolayı hürmetten kaçınma, Rabbiyle zengin olma ve zenginliğine şükretme, Müslümanlara merhamet ve iyilik etme, dili yalandan, giybetten, kulağı haram işitmekten koruma, gözü haramlara yumma, amellerde ihlaslı olma, dışa dikkat edip içi gözetleme, yaratıklarda iyilik görme, iyilerle arkadaş olma, dünyadan

13 Abdülbaki Gölpınarlı, Melâmilik ve Melâmiler, İstanbul, Gri Yayınc1lık, 1992, s.76.,

14 Bolat, age., s.280.

15 Süleyman Uludağ, "Fütüvvet", DİA, c.12, İst. 1996, ss.259-260.

16 Ebu'l-Hasan Ali b. Osman el-Hucvirî, Keşfu'l-Mahcub, çev. Süleyman Uludağ, İstanbul,Dergah Yayınları, 1982, s.123.

17 Hucvirî, age., s.123.

18 Ebu'l-Kasım Abdülkerim b. Hevâzin el-Kuşeyrî, er-Risaletü'l-Kuşeyriyye, tah. Abdülhalim Mahmud, Kahire, 1974, c.2, s.473. 
yüz çevirme, Allah'a yönelme, böbürlenmemek, hiç kimseden çekinmeden hakk1 söyleme, mecliste aşağı oturmaya razı olma, kendi hakkını istemekten vazgeçme ve başkalarının hakkını tam verme, yokluk sırasında yalnız Allah'a güvenme, aza tamah etme, günâhkârlara şefkat etme, kimseyi rahatsız etmeme, dışının içine uymasına özen gösterme, uzakta olsa bile dostu ziyâret etme, dostunun dostuyla dost, düşmanıyla düşman olma." ${ }^{19}$

Nişâbur ekolüne mensup sûfîler, fütüvvet anlayışlarının yanı sıra tasavvufa melâmet adıyla farklı bir düşünce tarzı kazandırmışlardır. Esasında onların fütüvvet anlayışları Melâmiliğin doğuşuna zemin hazırlamış, teşekkülünde rol oynamıştır. ${ }^{20}$ Tasavvufun şekilci bir hal almasına tepki duyan Horasanlı sûfîlerin ortaya koyduğu melâmetiliğin önderi olarak Hamdûn el-Kassâr (ö.271/884) gösterilmiştir. ${ }^{21}$ Kur'an'da geçen: "Onlar kınayanların kınamalarından korkmazlar. $\mathrm{Bu}$ Allah'ın bir lutfudur ki, onu dilediğine verir. Allah her şeyi kuşatandır, bilicidir." 22 "Kendini kınayan nefse yemin ederim." ${ }^{23}$ şeklindeki ayetlere dayandırılan melâmet anlayışı zaman içinde; iddia sahibi olmama, riyâdan sakınma, şöhretten uzak durma, nefsi itham ederek onun ayıplarıyla meşgul olma, amelleri görmeme gibi anlamlar kazanmıştır. Böylesi selbî bir anlayışa sahip olan melâmîler, nefislerini ayıplayıp, suçladıkları ve onun kusurlarından bahsettikleri kadar, nefislerini övmez; riyâdan konuştukları kadar, ihlâstan söz etmezler. Amellerin eksik ve kusurlarından konuşmayı onların faziletlerinden konuşmaya tercih ederler. ${ }^{24}$ Bunun yanında Sülemî, yukarda fütüvvet ilkeleri olarak zikrettiğimiz ilkelerin hemen hepsini melâmet ilkesi olarak da zikretmiştir yani söz konusu ilkeler melâmet içinde geçerlidir. ${ }^{25} \mathrm{H}$. III.ve IV. yüzyılda melâmetî olarak tanınan sûfîler arasında; Hamdûn Kassâr, Ebû Osman Hîrî, Ebû Hafs Haddâd, Ebu Türab Nahşebî, Ahmed b. Hadraveyh, Abdullah b. Münâzil (ö.331/942), Ebû Amr b. Nüceyd (ö.365/975), Bâyezîd-i Bistâmî (ö.261/875), Muhammed b. Ahmed el-Ferrâ (ö.360/971) gibi isimleri sayabiliriz. ${ }^{26}$ Başlangıçta Irak ve diğer bölgelerde gelişen tasavvuf hareketine bir tepki olarak ortaya çıkan melâmetîlik, daha sonra tasavvufî sistem içinde bir yandan bir meşrebin adı olma özelliğini kazanırken diğer yandan bir tarikatın adı olmuştur. ${ }^{27}$ Melâmet hareketinin gelişimi, 1.Melâmiyye-i Kassâ-

19 Ebû Abdurrahman es-Sülemî, Kitâbu'l-Fütüvve (Tasavvufta Fütüvvet), nşr. ve çev. Süleyman Ateş, Ankara, AÜİF yayınları, 1977, s.93-94.

20 Ebu'l-Alâ Afîfî, İslâm Düşüncesi Üzerine Makaleler, çev. Ekrem Demirli,İstanbul, İz yayınc1lik, 2000, s. 166.

21 Hucvirî, age., s.148.

22 Kur'an, Maide ,5/ 54.

23 Kur'an, Kiyamet ,75/ 2.

24 Afifi, age., s.86.

25 Bolat, age., s.293.

26 Bolat, age., s.18.

27 Hasan Kamil Yılmaz, Anahatlarılla Tasavvuf ve Tarikatlar, İstanbul,Ensar Neşriyat,1997, s. 113-114. 
riyye, ilk Devre Melâmileri 2.Melâmiyye-i Bayrâmiyye Orta Devre Melâmileri 3.Melâmiyye-i Nûriyye, Son Devre Melâmileri, şeklinde 3 kategoride ele alınmıştır. ${ }^{28}$ Bizim araştırmamızın konusunu ise Melâmiyyey-i Kassâriyye şeklinde adlandırılan ilk devre melâmileri oluşturmaktadır. Sonraki dönemlerin aksine ilk devre melâmîleri meşru bir gayeye ulaşmada kullanılan vasıtanın da meşru olmas1 gerektiğine inanmaktaydılar. ${ }^{29}$

Esasında Horasan bölgesinde ortaya çıkan fütüvvet ve melâmet anlayışlarını kesin çizgilerle birbirinden ayırmak oldukça zordur. ${ }^{30}$ Melâmilerin öğretilerinin büyük bir kısmı fütüvvet ehlinin öğreti ve adetlerinden beslenmiştir. Buna göre melâmiler, Müslüman zâhidlerin gerçek fetâlarıdır ${ }^{31}$ dememiz yanlış olmaz. Öyle ki kaynaklarda melâmetiliğin kurucuları arasında sayılan isimler aynı zamanda fütüvvet ehli olarak da zikredilmiştir. ${ }^{32} \mathrm{Bu}$ isimlerin çoğunun haddâd, kassâr şeklinde meslek adıyla anılması ve birçoğunun esnaf olması dahi melâmetîliğin fütüvvet ilkeleriyle nedenli örtüştüğünü göstermektedir. ${ }^{33}$ Esasında fütüvvet ve melâmet aynı gerçeğin iki farklı yönüdür. ${ }^{34}$ Her iki anlayışın ilkelerini tespit eden Sülemî, Melâmiliğin esasları arasında çok sayıda fütüvvet ilkesi zikretmiştir. Neticede ilk dönem fütüvvet ve melâmet anlayışlarının birbiriyle iç içe bir görünüm sergilediklerini söyleyebiliriz. Söz konusu bu durumu hanım sûfîlerde de görmekteyiz. Şöyle ki kaynaklarda Emetü'l-Aziz (Hevrâ) gibi fütüvvet ehli olarak tanıtılan bazı hanım sûfîlerden melâmî düşünceyi yansıtan rivayetler de zikredilmiştir.

Nişâburlu hanım sûfîlerin melâmet ve fütüvvet anlayışlarını tespitte yararlandığımız en önemli kaynağımız, Ebu Abdurrahman Sülemî'nin sadece kadın sûfîlerin tanıtımına tahsis ettiği, "Zikrü'n-Nisveti'l-Müteabbidâti's-Sûfîyyat" isimli eseridir. Aynı zamanda melâmet ve fütüvvet ilkelerini müstakil eserlerde tespit edip derleyen bir müellif olan Sülemî, hanım sûfîlerle ilgili kaleme aldığı bu eserinde, fütüvvet ehlinden ve melâmetî eğilime sahip çok sayıda hanım sûfîye yer vermiştir. Sülemî'nin eserinin ilginç bir de serüveni vardır. Varlı̆̆ 1 bilinmesine rağmen uzun yıllar kayıp olan bu eser, ${ }^{35} 1991$ yılında araştırmacı Dr. Mahmut Muhammet et-Tanahî tarafından keşfedilmiş ve tahkiki yapılıp ilim dünyasına

28 Gölpınarlı, age., ss.3, 31, 229; Bolat,age..,s .19

29 Bolat, age., s.395.

30 Bolat, age.,s. 290.

31 Afîfî, Makaleler, s.154.

32 Uludağ, Dört Kapı Kırk Eşik İslam Toplumlarında Sûfí Gelenekler ve Derviş Tipleri, İstanbul,Dergâh yayınları, 2009, s.153.

33 Sara Sviri, "İlk Dönem Tasavvuf Kültüründe Melâmetiyye Hareketi ve Hakîm Tirmîzî”, Tasavvuf Dergisi, çev. Salih Çift, sayı 11, İstanbul, 2003 s. 461.

34 Afîfi, Makaleler, s.193.

35 Smith, age., ss.32-33; Annemarie Schimmel, Ruhum Bir Kadındır, çev. Ömer Enis Akbulut, İstanbul, İz yayıncılık, 1999, s.23. 
kazandırılmıştır. Eser özellikle Horasan bölgesi kadın sûfîleriyle ilgili başka kaynaklarda yer almayan çok sayıda, kısa malumat içermesiyle de ayrı bir önemi haizdir. Eserde bahsi geçen hanımların çoğu devrin ileri gelen siyaset adamlarının ve sûfîlerin eşleri, ${ }^{36}$ diğerleri de büyük ölçüde zamanın önde gelen sûfîlerinin kızları ve müridleridir. Şu bir gerçek ki, gerek Nişaburlu hanım sûfîler gerekse diğer ekollerde yetişmiş sûfî hanımlar, İslâmın ilk yılllarında hanım sahâbîlerin sergiledikleri güzel ahlâkı, manevî hayata olan yönelimi devam ettirmişlerdir. İçlerinde Hz. Hatice gibi bütün mal varlığını eşine ve onun önderlik ettiği davaya vakfeden îsâr sahibi hanımlar olduğu gibi Hz. Âişe örneğinde görüldüğü üzere eşlerinin görüşlerini insanlara rivâyet ederek ilme hizmet eden hanım sûfîler de mevcuttur. Hz. Âsiye, Hz. Meryem, Sahâbî hanımlar, Hz. Peygamberin eşleri annelerimiz, kadın evliyâlar âdeta kutlu bir zincirin halkalarıdırlar. İslâm mânevî hayatının bu güne ulaşmasında söz konusu silsilenin katkısı yadsınamaz. Şüphesiz, Nişâburlu hanım sûfîler de bu zincirin en kuvvetli halkarından biridir.

\section{Nişâbur Ekolüne Mensup Hanım Sûfilerde Görülen Fütüvvet Anlayışı}

H III-IV. asır Nişâburlu hanım sûfîlerde görülen fütüvvet; îsâr, kendini hizmete adama, tevekkül, eziyet vermemek, iyiliği yaymak, sızlanmayı bırakmak gibi anlamlar içermektedir. Söz konusu dönemde hanım sûfîlerin yakınındaki isimler Bâyezîd-i Bistâmî, Zünnûn Misrî (ö.245/859), Hâtim el-Esam, Ahmet b. Hadraveyh, Ebû Osman Hîrî, Ebû Abdullah es-Siczî, Ebu Muhammed Mevsilî, Hamdûn Kassâr, Şiblî (ö.334/945) şeklinde tespit edilmiştir.

Horasan bölgesinde yetişmiş ilk hanım sûfîlerden en meşhuru 203/818 $8^{37}$ ve 223/83738 yıllarında vefat ettiğine dair, hakkında iki ayrı rivayet bulunan, Fâtıma Nişâburî'dir. Bâyezîd-i Bistâmî'nin övgülerine mazhar olan, Zünnûn Misrî̀nnin kendisinden bazı meseleleri sorup öğrendiği Fâtıma Nişâburî’nin ${ }^{39}$ tasavvuf düşüncesinde Horasan tasavvufunun ilk temsilcilerinde gördüğümüz tevekkül an-

36 Mustafa Așkar, “Ebu Abdurrahman Sülemî'nin Zikru'n-Nisveti'l-Müteabbidâti's-Sûfiyyat Adlı Eserinde Kadın Sûfilerin Yeri”, AÜIFF, c.37, Ankara,1997, ss.405-406.

37 Ebu Abdurrahman Sülemî, Zikru'n-Nisveti'l-Müteabbidatis-Sûfìyyat, tah. M. Muhammed Tanahî, Kahire, Mektebetü'l-Hancî, 1993, s.62; Nûreddin Abdurrahman b. Ahmed el-Camî, Nefahatü'l-Üns min Hadarâti'l-Kuds, çev. ve şerh. Lâmiî çelebî, haz. Süleyman Uludağ-Mustafa Kara, İstanbul,Marifet Yayınları, 1995, s.850; Zeyneb bt. Yusuf Fevvaz el-Amilî, Durrûl-Mensûr fi Tabakati Rabbati'l-Hudûr, Beyrut,Daru'l-Marife, 1312, s.368.

38 Cemâlüddin Ebu'l-Ferec Abdurrahman İbnü'l-Cevzî, Slfatü s-Safve, tah. Mahmud Fahurî-Muhammed Kal'acî, Beyrut, Dâru'l-Marife,1979, c.4,s.124; Abdulvehhab b. Ahmed b. Ali elEnsârî eş-Şaranî, et-Tabakatü'l-Kübrâ, Misır, Matbaatü Mustafa el-Bâbi'l-Halebî, 1954, c.1, s.66; Yusuf b. İsmail b. Hasen b. Muhammed en-Nebhanî, Camiu Keramati'l-Evliya, Beyrut, Daru'l-Marife, 1994, c.2, s.435.

39 Sülemî, age., s.61; İbnü'l-Cevzî, age., c.4, s.124; Camî, age., s.849; Şaranî, age., c.1, s.66; M. Zihni Efendi, Meşahiru'n-Nisâ, sad. Bedrettin Çetiner, Şamil yayınevi, İst., 1982, c.2, s.126; c.4, s.124; Amilî, age., ss.365-368. 
layışına rastlamaktayız. Dolayısıyla Fâtıma Nişâburî'nin fütüvvet anlayışının tevekkül merkezli olduğunu söyleyebiliriz. Zünnûn Mısrî ile aralarında geçen şu olayda Fâtıma, Zünûn Mısrî’ya yolun inceliklerini hatırlatmış, bu konudaki iddasını ortaya koymuştur. Rivâyete göre Fâtıma Nişâburî, Zünnûn Mısrî’ya bir hediye yollamış, Zünnûn Mısrî ise bu hediyeyi, "Hatunlardan bir şey kabul etmek de zillet ve kusur vardır.” diyerek reddetmiştir. Zünnûn Mısrî’nin bu davranışı karşısında Fâtıma Nişaburî, "Gerçek sûfîler (verenle alan) arasında vasıta görmezler, (veren Allah'a verir, alan da O'ndan alır)" diyerek, ${ }^{40}$ O'nun tasavvuf düşüncesini eleştirmiştir.

Fâtıma Nişâburî gibi tevekkül düşüncesine önem veren Horasanlı hanım sûfîlerden bir diğeri de Hâtim el-Esâm'ın karısıdır. İsmi kaynaklarda geçmeyen bu hanım, eşi Hâtim el-Esâm gibi tevekkül kavramı üzerinde 1srarla durmaktadır. Hatta onun bu konuda geldiği nokta eşinin de önündedir. Nitekim Rum topraklarına gazaya gidecek olan Hâtim el-Esam, eşine ne kadar nafaka hazırlaması gerektiğini sormuş; karısı, "Hayatımı idâme ettirecek kadar." sözleriyle cevaplamıştır. Bu cevap üzerine Hâtim el-Esâm, "Senin hayatını idâme ettirmek benim elimde değil ki!" deyince; karısı, "Peki benim rızkım senin elinde mi ki!" yanıtını vermiştir. Daha sonra bu hanıma kocasının ne kadar nafaka bıraktığı sorulduğunda ise, "Hâtim de benim gibi rızık yiyendir. Rızık veren buradadır, bir yere gitmedi" diyerek ${ }^{41}$ tevekkül düşüncesini ortaya koymuştur.

Hicrî III. ve IV. asırda fütüvvet ve melâmet, bölge sûfîlerinin hâkim anlayışı haline gelmesiyle, özellikle Nişaburlu sûfiler fütüvvetin tarifini yapmaya, ilkelerini tespit etmeye başlamıştır.

Fütüvvet anlayışına sahip Nişâburlu hanım sûfîlerin önde gelen temsilcilerinden biri de zamanın Belh Emîri’nin kızı Ümmü Ali’dir. Asıl adı Fâtıma olan ve bu yüzden Fâtıma Nişâburî ile karıştırılan bu hanım, ${ }^{42}$ fütüvvet ehlinden Ahmed b. Hadraveyh ile evli idi. Farklı hikâyesi ile dikkat çeken Ümmü Ali'nin yaşamıyla ilgili ayrıntılar, kaynaklarda detaylı bir şekilde anlatılmıştır. ${ }^{43}$ Ümmü Ali'nin görüşmüş olduğu sûfîlerden Bayezîd-i Bistâmî ve Ebû Hafs Haddâd, Fâtıma’nın yani Ümmü Ali'nin tasavvuftaki bilgisine hayran kalmış, ona övgülerde bulunmuşlardır. ${ }^{44}$ Hiç şüphesiz, Ümmü Ali’nin fütüvvet anlayışını benimsemesindeki

40 Sülemî, age., s.61, İbnü’l-Cevzî, age., c.4, s.124; Camî, age., s.849; Cevad Nurbahş, Sûfî Women, translated: Leonard Lewisohn, London:Khaniqahi-NimatullahiPublication, 1990, s.162.

41 Feridüddin Attar, Tezkiretü'l-Evliya, çev. Süleyman Uludağ, İstanbul:Mavi yayıncılık, 2002, c.1, s.295; Nurbahş, age., s.190.

42 Bkz. Annemarie Schimmel, Islamın Mistik Boyutlarl, ss.414-415; Aynı yazar, Ruhum Bir Kadindir, s.43.

43 Sülemî, age., s.76; Ebû Nuaym İsfehânî, Hilyetü'l-Evliyâ ve Tabâkâtü'l-Asfiyâ, Beyrut:Daru'l-Küttabi'l-Arabî, 1405, c.10, s.42; Camî, age., s.851; Hucvirî, age., s.220; Attar, age.,c.1, s.343; Nurbahş, age., s.92.

44 Sülemî, age., s.76; Hucvirî, age., s.220; Attar, age.,c. 1, s.344. 
en büyük etken, tasavvuf yolunda kendisine rehber olarak gördüğü kocası Ahmed b. Hadraveyh'di. Ümmü Ali ve eşinin evlerini ziyarete gelecek olan "fityan reisi" (Yahya b. Muaz Razî) için gösterdikleri hürmet ${ }^{45}$ bu anlayışa sahip kimseleri ne denli önemsediklerini göstermektedir.

Sûfî düşüncede fütüvvet, ağırlıklı olarak îsar merkezli ele alınmıştır. ${ }^{46}$ Ümmü Ali ve diğer Nişâburlu hanım sûfîler için de benzer durum söz konusudur. Ümmü Ali tevbe edip tasavvuf yoluna girdikten sonra malının çoğunu fakirlere dağıtmış, Ahmed b. Hadraveyh ve arkadaşlarına maddi yardımda bulunmuştur. ${ }^{47}$ Bir hayli zengin olan Ümmü Ali malının çoğunu fakirlere dağıtmış, fakirlik hususundaki, "Fakir kalacağımı düşünmem, yalnızca Rabbimin zenginliğini düşünürüm. Böylece fakirliği yaşamam. Kendi kendime, O'nun gibi bir efendisi olan nasıl fakir olur ki? derim" sözleriyle ${ }^{48}$ tevekkül anlayışını ortaya koymuştur.

Bilindiği gibi fütüvvet anlayışında başkalarına hizmet etmek esas kabul edilirken, başkalarından böyle bir tutum beklenmez. Benzer anlayışa sahip Ümmü Ali'ye Belh'den bir hanım gelmiş ve Allah'a yakın olmak için ona hizmet etmek istediğini söylemiştir. Ümmü Ali ise kadına, "Niçin Allah Teâla'ya hizmeti vesile edip, bana yakın olmayı talep etmiyorsun?” şeklinde cevap vermiştir ${ }^{49}$

Ümmü Ali kendisine hizmette bulunmak isteyen bu hanımın teklifini reddetmiş olsa da fütüvvet ehline hizmetin faziletine inanmak, hanım sûfîlerde rastlanan bir özelliktir. İki arkadaş sûfî Âişe Merveziyye ve Amrâ Fergâniyye, fütüvvet ehline hizmetin manevi alanda kişiye sağlayacağ kazanımlar üzerinde durmuşlardır. Bu hanımlardan Âişe Merveziyye, Ahmed b.Seriy (ö.357/967) ile evlenmiş, Ebû Osman Hîrî'nin tasavvuf düşüncesinden etkilenmiş bir sûfî idi. Aişe Merveziyye hizmet hususunda, "Fütüvvet ehlinden birine bir mevzuda yardımc1 olduğumda, sırrımda bir nur bulurum. Onun hizmetini ve gereklerini yerine getirdiğimde bu nur bende tamamlanır. Hizmetini kısa kestiğimde de bu nur söner." demiştir. ${ }^{50}$ Âişe Merveziyye'nin kendisinden rivayetlerde bulunduğu sûfî Amrâ Fergâniyye de tıpkı Âişe Merveziyye gibi fütüvvet ehline ve diğer insanlara hizmetin faziletinden bahsetmiştir. Mârifet ve fena konularında da görüşleri olan Amrâ, hür insanlara ve fütüvvet ehline hizmet eden kişinin halkın yanında itibar görüp, onların muhabbetini kazanacağını, hatta bu şekilde davranarak evliyalar derecesine ulaşabileceğini savunmuştur ${ }^{51}$

45 Kuşeyrî, age., c.2,ss. 474-475; Hucvirî, age., ss.220-221; Attar, age., c.1, ss.344.

46 Bolat,age.,s. 288.

47 Sülemî, age., s.76; Camî, age., s.851.

48 Sülemî, age., s.76; Camî, age., s.851.

49 Sülemî, age., s.77; Camî, age., s.851; Nurbahş, age., s.94.

50 Sülemî, age., s.90.

51 Sülemî, age., s.87. 
Halka hizmeti fütüvvet anlayışlarının önemli bir unsuru olarak gören hanım sûfîlerin, fütüvvetin tanımı ile ilgili açıklamaları da bu yönde olmuştur. Sülemî'nin fütüvvet ehlinden olduğunu özellikle vurguladığı, hayatı hakkında hiç bir bilgiye sahip olmadığımız hanım sûfî Fâtıma Hankâhiyye fütüvveti, "Ayrım gözetmeden hizmette bulunmaktır." ${ }^{2}$ şeklinde tanımlamıştır. Fâtıma Hankâhiyye'ye göre; ariflerin mutluluğu, fütüvvet ehlini görmekle, üzüntüsü de fütüvvet ehlinden ayrı kalmakla olur. ${ }^{53}$ Böylesine önemli ifadelerin sahibi Fâtıma Hankâhiye hakkında başka kaynaklarda hiçbir malumatın olmaması, şüphesiz tasavvuf ilmi açısından büyük eksikliktir.

Fâtıma Hankâhiyye de olduğu üzere, Sülemî’nin fütüvvet ehlinden olduklar1nı özellikle belirttiği hanım sûfîler arasında; Hevrâ adıyla tanınan Emetü'l-Azîz'i ${ }^{54}$ ve Ebû Abdulllah es-Siczî'nin eşi Ümmü Abdullah' ${ }^{55}$ görmekteyiz

Daha önce de belirttiğimiz gibi Nişâbur ekolüne mensup hanım sûfîlerin fütüvvet anlayışı büyük oranda îsâr merkezlidir. Bilhassa fakirleri öven, onlara yard1$\mathrm{m} 1$ ve hizmeti tavsiye eden ifadeleri, Sülemî'nin tespit ettiği fütüvvet ilkelerini ${ }^{56}$ birebir yansitmaktadır.

Yaşadığı çağın önde gelen sûfîleriyle kurduğu dostlukla dikkati çeken Merhâ Nâsibiyye, hakiki manada yaşanan fakirliği övmüş, "Fakir kişi, gerçek manada fakirliği yaşarsa, fakirlik izzet kıyafetine dönüşür." demiştir. ${ }^{57}$ Merhâ Nâsibiyye bu sözleriyle, suret fakirliğinden ziyade, kendinde bir varlık görmeme anlamındaki manevi fakirliği kastetmektedir. Dolayısıyla fakir kişiden kasıt sûfî düşünceye mensup kimselerdir.

Daha önce kendisinden bahsettiğimiz Âişe Merveziyye ve Ümmü Abdullah'tan da fakirler hakkında benzer ifadeler rivayet edilmiştir. Âişe Merveziyye, en fazla fakirlerle beraber yediği yemekten hoşlandığını belirtmiştir. ${ }^{58}$ Ebu Abdullah es-Siczî'nin eşi ve İbn Nüceyd'in dostu olan Ümmü Abdullah, fakirleri küçümsemenin tehlikesine değinmiştir ${ }^{59}$

Nişâbur'un önde gelen sûfîlerinden zühd ve vera sahibi Ahmed b. Hemedân'ın (ö.311/923) kızı, sûfî Ebû Bişr Helâvî’nin (ö.393/1002) annesi olan Ümmü Hüseyin de fakr yolunu övmüş, yolun zorluklarından haber vermiştir. ${ }^{60}$

52 Sülemî, age., s.123.

53 Sülemî, age., s.123.

54 Sülemî, age., s.104.

55 Sülemî, age., s.92.

56 Sülemî, Kitabü'l-Fütüvve (Tasavvufta Fütüvvet),ss.43-44, 93-94.

57 Sülemî, Zikru'n-Nisve., s.107.

58 Sülemî, age., s.90.

59 Sülemî, age., s.92.

60 Sülemî, age., s.113. 
Fakirliği ve fakiri öven hanım sûfîler, fütüvvet anlayışlarının bir gereği olarak, fakirlere yardımla ve onların ihtiyaçlarını gidermekle meşgul olmuşlardır. Rey'le Nişâbur arasında bulunan Damegân' da ${ }^{61}$ yaşamış üç hanım sûfí; Abdûse bt. Hâris, Fâtıma bt. İmrân ve Melike bt. Ahmed b. Hayyeveyh fakirlere olan yakınlıklarıyla dikkat çekerler. Sülemî, Abdûse bt. Hâris'in uzun süre beldesindeki fakirlerin hizmetini gördüğünü rivâyet etmiştir. ${ }^{62}$ Ebû Muhammed Mevs1lî’nin, “O, zamanın Râbia’sıdır.” sözleriyle övdügü Fâtıma bt. İmrân'ın, ölümüne değin fakir ve garipleri gözettiği bildirilmiştir. ${ }^{63}$ Zamanın Damegân reisi Ahmed b. Hayyeveyh'in kızı Melike de, fakirlere yardımı seven îsâr sahibi bir sûfî idi. Melike aynı zamanda amcasının oğlu olan eşi Hasen b. Ali Hayyeveyh ile çıktıkları hac yolculuğunda yanlarında bulunan son paralarını da Medine'de gördüğü Sudanlı fakirlere dağıtmıştır. Hasen, Şiblî’nin, eşi hakkında kendisine söylemiş olduğu, "Sen erkeksin, $\mathrm{O}$ da kadın fakat $\mathrm{O}$ hal bakımından senden daha üstün." şeklindeki sözleriyle ne demek istediğini, bu olay sonunda anladığını îtirâf etmiştir. ${ }^{64}$

Fakirleri gözeten bir diğer sûfî hanım, kaynaklarda yaşamı hakkında hiç bir bilginin olmadığ 1 Âmine Merciyye'dir. Fakirlerin sorumluluğunu üzerine almış olan Âmine, fakirlere hizmet etmenin kalbin nûru, sırrın salâhı olduğu düşüncesindeydi ${ }^{65}$

Ebû Osman Hîrî'nin müridi Fâtıma bt. Ahmed b. Hani Nişâburiyye de fakirlere, Ebû Osman ve arkadaşlarına çok miktarda mal infâk etmiştir. Ebû Osman onun bu özeliğine işaret ederek, "Fâtıma'nın fakirlerle dostluğu, fityânın dostluğu gibidir. Dünya ve ahirette bu dostluktan karş1lık beklemez." sözleriyle onu övmüştür. ${ }^{66}$

Fütüvvet anlayışını îsâr merkezli değerlendiren bir diğer sûfî hanım Âişe bt. Tavil Merveziyye'dir. Fakirlere yüklü miktarda bağış yapmış olan Âişe bt. Tavil Merveziyye'ye göre; fakir yemeğinden zevk alamayan, fakirliğin faziletinden de bîhaberdir. Sürekli olarak yardımlarda bulunan Âişe bt. Tavil Merveziyye'ye, "Kadınlardan yardım kabul etmek zillettir, deyip yardımını kabul etmezlerse, ne yaparsın?" diye sorulmuş, $\mathrm{O}$ da böyle bir ayrıma şiddetle karşı çıkmıştır. ${ }^{67}$

Başkalarına mâddî ve mânevî yardımlarını esirgemeyen fütüvvet ehli hanımlar, kendi ihtiyaçlarını bildirmekten ve başkalarından yardım istemekten kaçınmışlardır. Nitekim sûfîlerin bu tavrı, Sülemî’nin tespit ettiği fütüvvet ilkeleri

61 Ebu Abdullah el-Yakut, Mu'cemü'l-Buldân, Dâru'l-Fikr, Beyrut, trs., c.2, s.433.

62 Sülemî, age., s.112.

63 Sülemî, age., s.111.

64 Sülemî, age., s.110.

65 Sülemî, age., s.122.

66 Sülemî, age.,s. 91.

67 Sülemî, age., s.124. 
arasında da yer almaktadır. ${ }^{68}$ Bu şekil bir anlayışa sahip olan Nişâburlu sûfî Futayme'nin fütüvvet düşüncesi, eşi büyük sûfî Hamdûn Kassâr'ın görüşleriyle paralellik arz etmektedir. Hamdûn Kassâr'a göre, ihtiyacını insanlara arz etmemek ve onlardan yardım istememek fütüvvetin bir gereğidir. O, mahlukun mahluktan yardım istemesini, mahbusun mahbustan yardım istemesine benzetmiştir. ${ }^{69} \mathrm{Ham}-$ dûn'la aynı düşüncede olan Futayme de, "Kalbin imarı dünyadan yüz çevirmekle olur, kalbin mahvolması da yaratılmışlardan yardım istemekle olur." demiştir. ${ }^{70}$

Futayme örneğinde olduğu gibi sûfî hanımlar, fütüvvet düşüncelerini oluştururlarken, çevrelerindeki bu anlayışın önde gelen isimlerinden büyük oranda etkilenmişlerdir.

Sonuç olarak; Nişâbur ekolüne mensup hanım sûfîlerde görülen fütüvvet anlayışı, zikredilen örneklerde de açıkça görüldügüü üzere isar merkezli bir anlayıştır. Halka hizmeti, fakirlere yardımı, ön plana alan fütüvvet düşüncesi, Nişâburlu hanım sûfîlerin ortak özelliğidir.

\section{Nişâbur Ekolüne Mensup Hanım Sûfîlerde Görülen Melâmet Anlayışı}

Melâmet fütüvvet temelinde gelişmiş bir anlayış olmakla beraber, meselelere olumsuz yaklaşımıyla fütüvvetten ayrılır. Dolayısıyla Nişâburlu hanım sûfîlerin özellikle; riyâ, ihlâs, nefsini küçük görme, aşağılama, özel kıyafet ve törenlere karşı olma gibi hususlardaki tavırlarıyla melâmetî tarzda bir anlayışa sahip olduklarını görmekteyiz. Bu dönemde melâmet ehli hanımların yakınında Hamdûn Kassâr, Ebû Abdullah b. Hafîf (ö.371/982), Ebû Amr b. Nüceyd, Ebû Kâsım Nasrabâzî, Ebû Abdullah b. Hafîf (ö.371/982), Ebû Ali Sekafî (ö.328/940), Abdullah b. Münâzîl (ö.331/942), Ebû Osman Hîrî, Ebû Abbas Dineverî (ö.340/951) gibi isimleri zikredebiliriz.

Bilindiği gibi melâmet düşüncesi büyük ölçüde riyâ endişesinden doğmuş bir anlayıştır. Dolayısıyla bu bölge sûfílerinin, riyanın karşı1ı olan ihlâs kavramı üzerinde 1srarla durduklarını görmekteyiz. Horasan bölgesinin ilk hanım sûfîlerinden olan Fâtıma Nişâburiyye da bu sûfîlerdendir. Fâtıma Nişâburiyye, ârifle ihlâs sahibini ayrıştırdığı sözünde muhlis olmanın farkını vurgulamış ve bu durumu şu şekilde açıklamıştır: "Hak Teâlâ'yı müşâhade mertebesine ereyim diye amel eden kimse âriftir. Allah beni müşâhede ediyor diye amel eden kişi de ihlâs sahibidir."

Fâtıma Nişâburiyye doğruluğun, kişinin gayreti sonunda Allah'ın muradı olduğunu düşünmüştür. Burada kula düşen, ihlâslı olmaktır. Ona göre, Allah'1 hatırına getirmeyen her konuda cüretkârdır, her şeyi konuşur ama kim müşâhede

68 Sülemî, Kitabü'l-Fütüvve, s.53.

69 İsfehanî, age., c.10, s.231.

70 Sülemî, Zikru'n-Nisve, s.95.

71 Sülemî, age., s.62; İbnü'l-Cevzî, age., c.4, s.124; Camî, age., s.850; Şaranî, age., c.1,s. 66. 
üzere olur, Hak Teâlâ'yı sürekli hatırlarsa, Allah Teâlâ ona sadece doğru şeyleri söyletir, onu hayâ ve samimiyetle donatır. ${ }^{72}$

İhlas konusuna dikkat çeken bir diğer sûfî hanım Ümmü Fadl olarak bilinen Vehediyye'dir. Nisbesini Yemen'in bir köyünden almış olan Vehediyye, ${ }^{73}$ hayatının çoğunu seyahat ederek geçirmiş bir sûfî idi. Öyle ki, bu seyahatlerin neticesinde, zamanın önde gelen sûfîlerinin çoğuyla görüşmüştür. Ömrünün sonuna doğru Ebu Abdullah b. Hafîf'le görüşmüş, ardından Nişâbur'a gidip burada İbn Nüceyd'le ve Ebû Kâsım Nasrabâzî ile bir araya gelmiştir. Vehediyye'nin ilminden ve sohbetinden yararlanmak isteyen sûfî büyüklerinden de onu ziyaret edenler olmuştur. Vehediyye giderek nazarî bir hal alan tasavvuf hareketine görüşleriyle önemli katkı sağlamıştır. Onun, diğer fikir akımlarından ayrılarak, ayrı bir hüviyet kazanan tasavvuf hareketini tarif edip, bu hareketin mensuplarının vasıflarını belirlemesi ise tasavvuf tarihi açısından ayrı bir önem taşımaktadır. Böylesi etkin bir tasavvufî yaşamı olan Vehediyye, melâmet anlayışının ön koşulu olan ihlâslı davranmak üzerinde durmuştur. Özellikle ilimle meşgul olurken ihlâslı hareket edilmesi gerektiğini vurgulayan Vehediyye, sanıldığı gibi, ilimle amel etmenin çokça ibadet ederek olamayacağını; ilimle amelin, Allah'a ihlasla amel ederek olacağını savunmuş, ihlaslı amelin de sahih bir niyet ve Allah'ın nazarını üzerinde hissetmekle gerçekleşebileceğini söylemiştir. ${ }^{74}$

Benzer konuya değinen bir diğer Nişâburlu hanım sûfî Ebu Amr b. Nüceyd'in hanımı Fahraveyh bt. Ali (313/925)'dir. Fahraveyh bt. Ali Nişâbur Ekolü içinde melâmetî anlayışın öncü isimleri arasında yer almıştır. Bu anlayışın gereği olarak, riyadan uzak durup, ihlaslı olmanın önemini vurgulamıştır. Özellikle ilmî konularda konuşulurken bu hususa dikkat edilmesi gerektiğinin altını çizmiş, ilmin amelle tamamlanmas1 gerektiğine vurgu yapmıştır. ${ }^{75}$

Melâmetiliğin fikir olarak üzerinde 1srarla durduğu temel prensip, Sülemî’nin eserinde de belirttiği üzere riya ile mücadeledir. ${ }^{76}$ Amel ve hallerin nefsin kendisine bir pay çıkarabileceği endişesiyle gizlenmesi melâmetîliğin vazgeçilmez ilkesidir. ${ }^{77}$ Mücahade sahibi bir sûfî olan Avne Nişâburiyye'nin riya endişesiyle, "Zina eden kişinin zinasından, hırsızın hırsızlığından tevbe ettiği gibi namazımdan ve orucumdan tevbe ederim." şeklinde söylediği sözler, onun melâmet anlayışını göstermektedir. ${ }^{78}$

72 Sülemî, age., s.62; ibnü'l-Cevzî, age., c.4, s.124; Camî, age., s.849; Şaranî, age., c.1, s.66; Amilî, age., s.367.

73 Yakut, age., c.5, s.392.

74 Sülemî, age., s.106.

75 Sülemî, age., s.80.

76 Sülemî, "Risaletü'l-Melâmetiyye", haz. Ebu'l- Alâ Afifî, Mecelletü Külliyeti'l-Âdâb, Kâhire, 1942, c.6, s. 81.

77 Bolat, age., s.178.

78 Sülemî, Zikru'n-Nisve, s.103. 
Melâmetiler riya endişesiyle hallerin gizli olması gerektiğine inanırlar. ${ }^{79}$ Hâle adıyla tanınan Ümmü Gülsüm, vecd hususundaki görüşleriyle melâmetî anlayışın bu konudaki tavrını yansıtmıştır. Ebu Ali Sekafî, Abdullah b. Münâzîl, Ebû Kâsım Nasrabâzî gibi sûfîlerle dostluğu olan Ümmü Gülsüm'ün tasavvuf yaşamında vecd hali önemli bir yere sahiptir. Yakın dostu Ümmü Hüseyin'le çıktıkları bir dağ gezisinde yaşadığı vecd hali, kaynaklarda anlatılmaktadır. Ümmü Gülsüm, melâmet anlayışın gereği olarak, vecd halinde riyakar davranılmaması gerektiğini savunmuştur. Ona göre; vecd halinde, yapmacık davranan kişinin zorlama tavırları belli olur, bu hal kulda Allah'ın sırrıdır. Allah onu açık etmek istediğinde meydana çıkarır, gizlemek istediğinde ise saklar. ${ }^{80}$ Özetle; Ümmü Gülsüm, vecd halindeki bir kişinin sürekli riya tehlikesiyle karşı karşıya olduğunu söyleyerek, gizliliğin esas olması gerektiğini ifade etmiştir

Daha önce kendisinden bahsettiğimiz Âişe bt. Ahmed Tâvil Merveziyye de melâmetiyyedeki gizlilik ilkesine vurgu yapmış, bilhassa kadınlar için keşfin gizli kalmasının, daha iyi olacağını belirtmiştir. ${ }^{81}$

Yine bu konuyla alakalı bir başka melâmetî ilkesi de kerametleri gizlemek, bunları istidrâc ve hak yolundan ayıran hileler olarak değerlendirmektir. ${ }^{82}$ Bâyezîd-i Bistâmî'nin yaşadığı yer olan Bistam yakınlarındaki Nevkabız köyünden sûfî Emetullah el-Cebeliyye ile Bâyezîd-i Bistâmî arasında geçen olayda, bu ilkenin önemi vurgulanmaktadır. Bâyezîd-i Bistâmî'nin kendisinden övgüyle söz ettiği Emetullah el-Cebeliye, izhar ettiği kerametlerle tanınmış bir sûfî idi. Rivâyete göre; sürekli keramet gösteren Emetullah'1 Bâyezit yanıltarak, eşi Abdullah el-Cebeliyye'nin yanında zor durumda bırakmıştır. ${ }^{83}$ Şüphesiz, Bâyezîd-i Bistâmi'nin böyle davranmasında, Emetullah'1 yalancı durumuna düşürmek gibi bir niyeti yoktur. Sülemî onun bu hareketini, "Bâyezît bununla Emetullah'in durumunu kocasından gizlemek istemiştir." şeklinde yorumlamıştır. ${ }^{84}$ Sonuçta Bâyezîd-i Bistâmî sûfî dostu Emetullah el-Cebeliye'ye kerametlerin gizlenmesi gerektiği hususunda bir ders vermiştir.

Sülemî’nin tespit ettiği melâmetîliğin ilkeleri arasında; nefsi hor görme, nefis ister itaat etsin, ister isyan etsin her halükarda onu itham etme, nefsin hiç bir halinden razı olmadan, onunla düşman olmak vardır. ${ }^{85}$ Ebû Osman Hîrî, Ebû'l-Abbas Dineverî gibi fütüvvet ve melâmet ehlinin önde gelen iki sûfisiyle kurduğu münasebetle dikkat çeken Fâtıma bt. Hecafiyye'de nefsi itham eden bir anlayış

79 Sülemî, Risale, s.94.

80 Sülemî, age., s.114.

81 Sülemî, Zikru'n-Nisve, s.124.

82 Sülemî, Risale, s.101.

83 Sülemî, Zikru'n-Nisve, ss.96-97.

84 Sülemî, Zikru'n-Nisve, ss.96-97.

85 Sülemî, Risale, s.82. 
görmekteyiz. Nefsin daima aşağılanması gerektiğine inanan Fâtıma bt. Hecafiyye, "Biri diğerine "ahmak" dediğinde ona sadece, "Efendim, buyur!" diye karş1lık veririm" demiştir. Fâtıma bt. Hecafiyye'ye göre; bizler asıl düşmanımıza dost, dostumuza da düşmanca davrandığımızdan aptallık etmekteyiz. Nefis ve şeytan iki düşman olduğu halde, onlara dostça davranıyor, kitap ve sünnet kurtuluşumuz iken onlardan yüz çeviriyoruz. ${ }^{86}$

Melâmet ehlinin önderi ve bu anlayışın Nişâbur'da yayılmasında önemli hizmetleri olan Hamdûn Kassâr'ın eşi Fudayme'de de melâmetî anlayış görülmektedir. Nefsi kınamayı, ondan asla razı olmamayı tavsiye eden Hamdûn Kassâr ${ }^{87}$ gibi Fudayme de, nefsini bilen kişinin kulluk bilincinde olacağını, bu kimsenin de yalnızca Mevlâsıyla övüneceğini söylemiştir. ${ }^{88}$ Netice de Fudayme'nin tıpk1 eşi gibi, fütüvvet ve melâmet düşüncesine katkıları olmuş bir sûfî olduğunu söyleyebiliriz.

Melâmetîliğin başlıca ilkeleri arasında; insanların kusurları ile ilgilenmeyi terk edip, nefsinin kusurlarıyla uğraşmak ve böylece onun kötülügünden sakınmak, nefsi sürekli itham edip, onu sslah etmeye çalışmak, nefsin gizli kusur ve ayıplarıyla ilgilenmek gelir. ${ }^{89} \mathrm{Bu}$ tarz selbî bir anlayışa sahip olan Ebû Osman Hîrî'nin torunu Ümmü Ahmet, "Fiillerin hepsi kusurludur. Kusurdan uzak olmayan nefsin ayıbını bilemez. Kim kendinde bulunan kusura rıza gösterirse, bu durumu tedâvî olmaz. Allah onu bu kötü duruma vâris k1lar.” diyerek ${ }^{90}$ nefisle mücadelenin devamlı olması gerektiğine değinmiştir. Melâmetî anlayışın olaylara selbî yaklaşımını İbn Nüceyd'in hanımı Fahraveyh bt. Ali'de de görmekteyiz. O bir sözünde, "Hal zayıf, tehlike büyük, dava geniş, doğruluksa azdır." demiştir. ${ }^{11}$ Daha önce ihlasla ilgili düşüncelerini aktardığımız Fâtıma Nişâburiyye; sâdık ve muttakî bir kulun, nefsine karşı gösterdiği direnci, denizde dalgalarla boğuşan kişinin haline benzetmiştir. Ona göre; büyük bir denizde dalgalarla boğuşup bogulmak üzere olan kimse, kurtulmak için nasıl dua ediyorsa, muttakî bir kul da aynı samimiyetle Allah'a kurtuluşu için dua etmelidir. ${ }^{92}$

Melâmetîlerin en temel özelliklerinden biri, halktan farklı özel kıyafet giymeye karşı çıkmalarıdır. Hanım sûfîlerden bu mevzuya dikkat çeken Emetü'l-Azîz olmuştur. Hevra olarak bilinen Emetü'l-Azîz, üzerinde yünden kıyafeti olduğu halde yanına gelen bir kadına, şunları söylemiştir: "Kim yünlü giyinirse, insanların en safı olması gerekir. Ahlakî yönden insanların en iyisi, halka karşı en cö-

86 Sülemî, Zikru'n-Nisve, s.82.

87 İsfehanî, age., c.10, s.231; Şaranî, age.,c. 1, s.84; İbnü'l-Cevzî, age.,c.4, s.122.

88 Sülemî, Zikru'n-Nisve, s.95.

89 Sülemî, Risale, s.97.

90 Sülemî, Zikru'n-Nisve, s.102.

91 Sülemî, Zikru'n-Nisve, s.80.

92 Sülemî, Zikru'n-Nisve, s.62; İbnü'l-Cevzi, age., c.4, s.124; Camî, age., s.850. 
merti, insanların en tatlı huylusu, cömerti ve eli açığ 1 olması gerekir. Nasıl ki, elbisenle halktan ayrilıyorsan özelliklerinle de onlardan farklı olmalısın." ${ }^{93}$

Görüldüğü gibi, hanım sûfilerin melâmet anlayışlanı; riya, ihlas, nefsi itham, nefsi aşağılama gibi anahtar kavramlar etrafında şekillenmiştir.

93 Sülemî, Zikru'n-Nisve, s.104. 


\section{Sonuç}

Bu kısa çalışmamızda, Nişâbur ekolünde yetişmiş hanım sûfilerde görülen fütüvvet ve melâmet düşüncesini ana hatlarıyla ortaya koymaya çalıştık.

Nişâbur ekolüne mensup hanım sûfileri tanımamızda Sülemî'nin eserinin katkısı büyüktür. Zira Sülemî, fütüvvet ve melâmet anlayışlarının ilkelerini en erken tespit eden müelliflerden biri olmanın yanında, bu anlayışa mensup erken dönem hanım sûfiler hakkında detaylı malumat veren tek yazardır, dememiz çok da yanlış olmaz. Esasında Sülemî, fütüvvet ilkesi olarak zikrettiği pek çok özelliği melâmet ilkesi olarak da tespit etmiş, her iki kavramın yakın münasebetini ortaya koymuştur. Dolayısıyla da fütüvvet ehli olarak tanıttı̆g hanım sûfilerin birçoğundan melâmeti anlayışı çağrıştıran rivayetler nakletmiştir. Biz de Fâtıma Nişâburiyye, Futayme, Emetü'l-Azîz, gibi hanım sûfîleri her iki anlayışa ait yaklaşımlar sergiledikleri için hem fütüvvet ehli hem de melâmet ehli hanım sûfîler arasında zikretmeyi uygun gördük. Sonuç olarak; tüm bu anlayış farklılıklarını tasavvuf genel ismi altında değerlendirirsek, h. III-IV./m.IX-X yy Nişâbur ekolünde yetişmiş hanım sûfîlerin melâmet ve fütüvvet şeklinde adlandırılan tasavvuf anlayışlarında; ihlas, tevekkül, îsar, riya endişesi, kendini hizmete adama, nefisle mücadele gibi mevzuların öne çıktığını söyleyebiliriz.

Nitekim bahsi geçen sûfî hanımlar sadece devrin önde gelen erkek sûfîlerinin sözlerini bizlere ulaştıran bir râvi olmakla yetinmemiş, kendi özgün tasavvuf anlayışlarını da ortaya koymuşlardır.

Neticede bu çalışmamızda Nişâbur ekolüne mensup hanım sûfîlerin bölgenin mevcut tasavvuf anlayışını yansıttıklarını, devrin önde gelen erkek sûfîleriyle paralel görüş serdettiklerini, sûfîyâne tavır ve sözleriyle tasavvufî düşüncenin gelişiminde etkin rol oynadıklarını tespit etmiş bulunmaktayız 


\section{Kaynakça}

Afifî, Ebu'l-Âlâ, Tasavvuf İslamda Manevî Hayat, çev. Ekrem Demirli-Abdullah Kartal, İstanbul, İz Yayıncılık, 1996. bul, İz Yayıncılık, 2000.

, İslâm Düşüncesi Üzerine Makaleler, çev. Ekrem Demirli, İstan-

Âmilî, Zeyneb bt. Yusuf Fevvaz, Durrû'l-Mensûr fi Tabakati Rabbati'l-Hudûr, Beyrut, Daru'l-Marife, 1312.

Aşkar, Mustafa, “Ebu Abdurrahman Sülemî’nin, Zikru'n-Nisveti'l-Müteabbidati's-Sûfiyyat Adlı Eseride Kadın Sûfilerin Yeri”, AÜIFD, c.37, Ankara, 1997.

Attar, Ebu Hamid Muhammed b. İbrahim Feridüddin, Tezkiretü'l-Evliyâ, çev. Süleyman Uludağ, c.I-II, İstanbul, Mavi Yayıncılık, 2002.

Bolat, Ali, Bir Tasavvuf Okulu Olarak Melâmetîlik, İstanbul, İnsan Yayınları, 2003.

Camî, Nureddin Abdurrahman b. Ahmed, Nefahatü'l-Üns min Hadarâti'l-Ku$d s$, çev. ve şerh. Lâmiî Çelebî, haz. Süleyman Uludağ-Mustafa Kara, İstanbul, Marifet Yayınları, 1995.

Çubukcu, Hatice, İlk Dönem Hanım Sufiler (H.I-V/ M.VII-XI Yüzyıllar), İstanbul, İnsan Yayınları, 2006.

Demirci, Mehmet, “Ahîlik’te Tasavvufî Boyut: Fütüvvet”, Dokuz Eylül Üniversitesi Illahiyat Fakültesi Dergisi, c.7, İzmir, 1992.

Gölpınarlı, Abdülbaki, Melâmîlik ve Melâmîler, İstanbul, Gri Yayıncılık, 1992.

Hucvirî, Ebu'l-Hasan Ali b. Osman, Keşfü'l-Mahcûb (Hakikat Bilgisi), haz. Süleyman Uludağ, İstanbul, Dergah Yayınları, 1982.

İbnü'l-Cevzî, Cemalüddin Ebu'l-Ferec Abdurrahman, Slfatüs-Safve, tah. Mahmud Fahûrî-Muhammed Kal'aci, c.I-IV, Beyrut, Daru'l-Marife, 1979.

İsfehanî, Ebu Nuaym Ahmed b. Abdullah, Hilyetü'l-Evliyâ ve Tabakâtu'l-Asfiyâ,c. I-X, Beyrut, Daru'l-Küttabi'l-Arabî, 1405.

İsfehânî, Râgıb Hüseyin b. Muhammed, el-Müfredât fì Garîbi 'l-Kur'an, Kahire, 1961.

el-Kuşeyrî, Ebu'l-Kasım Abdülkerim b. Hevazzin, er-Risaletü'l-Kuşeyriyye, tah. Abdülhalim Mahmud, Kahire, 1974.

Küçük, Sezai, “Abdullah Ensârî el-Heravî’nin Tasavvufî Fütüvvet Risâlesi: “Kitâbu'l-Fütüvvet”, Sakarya Üniversitesi Illahiyat Fakültesi Dergisi, c.2, Sakarya, 2000. 
M. Zihni Efendi, Meşâhiru'n-Nisâ, sad. Bedrettin Çetiner, c.I-II, İstanbul, Şamil Yayınevi, 1982.

en-Nebhanî, Yusuf b. İsmail b. Hasen b. Muhammed, Camiu Kerâmâti'l-Evliya, c.I-II, Beyrut, Daru'l-Marife, 1994.

Nurbahş, Cevad, Sûfì Women, translated Leonard Lewisohn, London, Khaniqahi-Nimatullahi Publications, 1990.

Schimmel, Annemarie, İslamın Mistik Boyutları, çev. Ergun Kocabıyık, İstanbul, Kabalc1 Yayınevi, 2001. c1lik, 1999.

, Ruhum Bir Kadındır, çev. Ömer Enis Akbulut, İstanbul, İz Yayın-

Sviri, Sara, "İlk Dönem Tasavvuf Kültüründe Melâmetiyye Hareketi ve Hakîm Tirmîzî”, Tasavvuf Dergisi, çev. Salih Çift, sayı 11, Ankara, 2003.

Smith, Margaret, Bir Kadın Sûfi: Rabia, çev. Özlem Eraydın, İstanbul, İnsan Yayınlar1, 1991.

Sülemî, Ebu Abdurrahman, Zikru'n-Nisveti'l-Müteabbidâti's-Sûfiyyat, tah. M. Muhammed Tanahî, Kahire, Mektebetü'l-Hancî,1993.

, "Risaletü'l-Melâmetiyye", haz. Ebu'l-Ala Afifi, Mecelletü Külliyeti’l-Âdab, VI, Kâhire, 1942.

, Kitabu'l-Fütüvve (Tasavvufta Fütüvvet), nşr. ve çev. Süleyman Ateş, Ankara, AÜIIFD Yayınları, 1977.

Şaranî, Abdulvehhab b. Ahmed b. Ali el-Ensarî, et-Tabakatü'l-Kübra (Levâkıhu'l-Envar fì Tabakâti'l-Ahyar), c.I-II, Misır, Matbaati Mustafa el-Babi'l-Halebî, 1954.

Uludağ, Süleyman, Sûfi Gözüyle Kadın, İstanbul, İnsan Yayınları, 1995. , "Fütüvvet", DİA, c.13, İstanbul, 1996.

, Dört Kapı Kırk Eşik İslâm Toplumlarında Sûfí Gelenekler ve Derviş Tipleri, İstanbul, Dergâh Yayınları, 1997.

Yakut, Ebu Abdullah, Mu'cemu'l-Buldan, c. I-V, Beyrut, Daru'l-Fikr, trs.

Yılmaz, Hasan Kamil, Anahatlariyla Tasavvuf ve Tarîkatlar, İstanbul, Ensar Neşriyat, 1997. 
